Editorial Board

Advisor

Dr. Upendra Gautam Nepal

Managing Editor

Bhai Raja Manandhar eRG Nepal

Kathmandu, Nepal

Associate Editors

Rajendra P. Thanju

Nepal

Salil Devkota

Nepal

Dr. Rabin Shrestha Nepal

Dr. Amimul Ahsan

Sr. Lecturer

Dept. of Civil Engineering

(University Putra Malaysia)

Team Member

Nepal

Dr. David J. Molden

DG, ICIMOD (International Centre for

Integrated Mountain Development)

Prof. Dr. Kiran K. Bhattarai

(Environment Specialist)

Dr. Shree Govind Shah

(Environment Specialist)

Prof. Dr. Ramesh K. Maskey

(Head, Civil and Geomatics Engineering

Dept., Kathmandu University)

Prof. Dr. Ram Manohar Shrestha

(Emeritus Prof., AIT, Bangkok, Thailand)

Norway

Dr. Krishna Kant Panthi

(Asso. Prof., NTNU)

China

Prof. Dr. Liu Heng

Director General,

(International Centre of Small Hydropower, Hanghzou)

USA

John Garcia

(Principal : GANDA)

India

Dr. MP Sharma

(Asso. Prof., AHEC, IIT, Roorkee)

Dr. Vishnu Prasad

(Prof., Dept of Civil Engineering, MANIT, Bhopal)

\section{To Break the Vicious Circle of Energy Poverty}

E nergy is pre-requisite and an engine for economic growth and human development. Accessible to reliable, affordable and clean energy is vital to set development on a sustainable path. But, the nation is suffering from enormous economic losses as well as heightened inconvenience to the households due to the shortage of electricity despite huge hydropower potentiality in the country.

Besides, the present embargo, in addition to massive devastation by earthquake, has added multiple suffering to the people. It has also exposed us where we stand in terms of energy security.

Now, time has come to think and act, with concerted efforts, toward harnessing huge hydropower potential of the country and make country selfreliable in energy. The development of hydroelectricity potential of Nepal is utmost necessary, at present, for sustained economic growth of the nation.

Nepal's annual 224 billion cubic meter of surface run-off could generate an enormous 83,000 MW of hydro-electric power potential with 43,000 MW techno-economically viable. Hydropower is the only sustainable source of electricity in Nepal. Hydropower development can alleviate poverty and transform our society into a prosperous one. Yet, the present utilization of this vast potential is limited to less than $1 \%$ only.

We need to take following actions to eliminate impediment and constraint to create a conducive environment for rapid hydropower development in Nepal;

- Update the hydropower potential of the nation,

- Assess and update appropriately the domestic electricity demand with present day scenario, and future need,

- Policy and legal reforms to eliminate hurdles and constraints,

- Constitute all High Powerful Commission under the Prime Minister to look into the matter of water resources and hydropower development,

- Formulate Integrated Nepal Energy Policy (INEP) to be endorsed by all the political parties, and commitment to make these policies immune to political changes.

Hence, we all, the political parties, leaders, policy makers, government agencies, concerned authorities, developers, experts and the people must think and move forward to make Nepal a self-sufficient, hydroelectric power exporting HYDRO-powerful nation in this region.

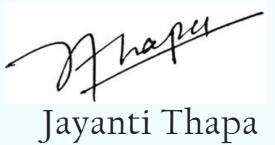

Editorial Officer 